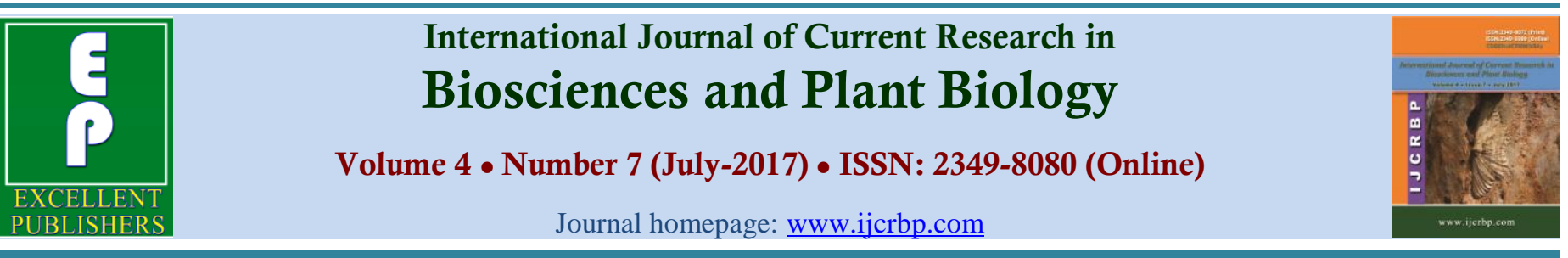

\title{
Characteristic Flavour of Robusta Coffee from South Sulawesi after Fermentation by Ohmic Technology
}

\author{
$\operatorname{Reta}^{1,2^{*}}$, Mursalim $^{3}$, Junaedi Muhidong ${ }^{3}$ and Salengke ${ }^{3}$ \\ ${ }^{I}$ Graduate School, Hasanuddin University, Makassar 90245, Indonesia \\ ${ }^{2}$ Department of Agroindustry, Agriculture Polytechnic Pangkep, Pangkep 90655, Indonesia \\ ${ }^{3}$ Departement of Agriculture Engineering and Food Technology, Hasanuddin University Makassar, Indonesia
}

*Corresponding author.

\begin{tabular}{|c|c|}
\hline Abstract & Article Info \\
\hline \multirow{8}{*}{$\begin{array}{l}\text { Coffee fermentation is a step of wet processing. The temperature of the fermented coffee } \\
\text { does not come from within, but is very dependent on the environment, temperature of } \\
\text { fermented from } 30,35 \text { and } 40^{\circ} \mathrm{C} \text { and duration of fermentation } 2,6,12 \text { and } 18 \mathrm{hrs} \text {. From } \\
\text { the research, fermentation time } 18 \text { hrs flavor, aroma and mouthfeel of the best, } 2 \mathrm{hrs} \\
\text { bittersweet the best, characteristic flavor of aromas found in coffee that comes from } \\
\text { Banateng flavored chocolate, caramelly, sweet teste, connilon, honeyed, spicy, buttery, } \\
\text { sweet potato and flowery. }\end{array}$} & $\begin{array}{l}\text { Accepted: } 14 \text { June } 2017 \\
\text { Available Online: 06 July } 2017\end{array}$ \\
\hline & Keywords \\
\hline & Aroma \\
\hline & Bittersweet \\
\hline & Coffee \\
\hline & Fermentation \\
\hline & Flavour \\
\hline & Ohmic technology \\
\hline
\end{tabular}

\section{Introduction}

The wet handling process is done by separating the fruit's skin (de-pulping), followed by fermentation, washing, drying, and removing the parchment skin (dehullering). The fermentation process can stimulate chemical changes that are useful in the formation offlavors precursor of the coffee beans, namely;organic acids, amino acids, and reduced sugars (Avallone et al., 2002; Bytof et al., 2005; Jackels and Jackels, 2005; Redgwel and Fischer, 2006; Lin, 2010). The wet handling process of coffee beans can produce better flavors than dry handling process (Subedi, 2011; Murthy and Naidu, 2011; Ferreira et al., 2013).
Wet coffee handling can produce better flavour compared to dry coffee handling (Subedi, 2011; Murthy and Naidu, 2011; Ferreira et al., 2013). Arabica and Robusta coffee beans can be treated wet and produce a distinctive taste of coffee. The wet bean processed coffee after roasting looks more attractive and with a rather white color on the groove in the middle of the seed pieces (Siswoputranto, 1992). Based on the results of research by Mondello et al. (2005) and Ferreira et al. (2013) reported that wet processing in Robusta coffee in Brazil produced better flavor quality than dry processing.

The most important condition of fermentation is 
temperature and fermentation time. The temperature of the fermented coffee does not come from within, but is very dependent on the environment. The length of fermentation time is determined by the processing stage such as soaking and drying. Robusta coffee generally takes a minimum fermentation time one day longer than Arabica coffee. The timing of fermentation varies between 48-72 hrs depending on the temperature and thickness of the lenders on the horns of the coffee horn (FAO, 2004). The process of fermentation is done by soaking the coffee beans by using water for approximately $72 \mathrm{hrs}$ (Clarke and Macrae, 1989). Most quality defect of coffee are attributed to inadequate control during fermentation and drying. The time required for digestion varies from 48 to $72 \mathrm{hrs}$ depending on temperature and thickness of mucilage in conventional coffee demucilage (Avallone et al., 2001). Some research on fermentation of coffee mostly use some kind of enzyme, but the fermentation temperature is not measured, so in this research try to pass a method of fermentation technology known as Ohmic fermentation technology system, which is known as technology heating technology system evenly.

Ohmic heating technology can be applied to a liquid product or a mixture of liquid-solid product (Salengke, 2000; Sastry, 2001; Salengke and Sastry, 2007). The use of Ohmic technology for the fermentation of coffee beans has not been done before. Therefore, the purpose of this research was to study the use of ohmic heating in the fermention of coffee beans and to assess the quality of the beans produced from the process.

The purpose of this research is to know the characteristic of fermented Robusta coffee flavor by using Ohmic fermentation technology with temperature treatment and fermentation time, hoping to produce the best flavor of coffee with Sensory Evaluation (SCAA) method.

\section{Materials and methods}

\section{Material}

The red coffee fruit used in this study is Robusta varieties, obtained from area garden in Bantaeng in South Sulawesi Indonesia with an altitude of $800 \mathrm{~m}$ asl. The red coffee fruit in the pulper to open the skin of fruit flesh. The fermented coffee uses ohmic fermentation technology with electrical heating system and ohmic tube capacity is 5 liters of water, with different treatment temperatures $\left(30,35\right.$ and $\left.40^{\circ} \mathrm{C}\right)$ and fermentation time
$(2,6,12$ and $18 \mathrm{hrs})$ with sample number 12 . The ohmic fermented coffee, washed thoroughly, then dried in the drying table until moisture content $<12 \%$. Horn leather coffee is in the huller to obtain coffee of rice or green coffee.

\section{Roasting}

The coffee sample is prepared according to SCAA testing standard (2012), weighing $150 \mathrm{~g}$ was roasted using BR22 Probot type roasting machine with a roasting temperature of $150^{\circ} \mathrm{C}$ for 25 minutes (Baggenstoss et al., 2008; Illy and Viani, 2005; Owen, 2009; Schenker et al., 2002; Sivetz and Desrosier, 1979; Yeretzian et al., 2002). Roasted coffee was ground well using Litina type grinder with a mesh size of 7.8 for 10 seconds. The sample to be tested should not exceed 30 minutes from the test time to ensure the freshness of the sample (Sivetz and Desrosier, 1979).

\section{Sample preparation and serving}

Ten 10 grams of coffee samples in hot water was brewed with a temperature of $99^{\circ} \mathrm{C}$ and $150 \mathrm{ml}$ water volume using ceramic bowl. The reason for using ceramic base materials in testing is that the coffee is very quickly reacting with foreign objects or other materials around it. The data samples are repeated up to 3 times.

\section{Sensory analysis}

\section{Cupping method}

Sensory analysis performed in accordance with SCAA standard method (2009). Roasted coffee samples, stored for $24 \mathrm{hrs}$, before grinding. The use of clean, odor-free water and has a soluble solid $125-175 \mathrm{ppm}$, Water is boiled with a temperature of $95-99^{\circ} \mathrm{C}$ and poured directly on a sample of ground coffee in the bowl. Panelists trained in this sensory test numbered 9 people ( 3 women and 6 men, together 37-55 years old) who are panelists in the laboratory of Indonesian Coffee and Cocoa Research Center, Jember, Indonesia. Samples were taken randomly with replication of 3 times from 9 descriptors. Quality of steep coffee can be evaluated by Aroma, Acidity, After test, Flavor, Clean cups, Mouth feel and overall quality. The quality and intensity of all profile descriptions were evaluated simultaneously using a scale varying from 1 to 5 according to Riberio et al. (2011). 


\section{Data analysis}

Data is collected using Compusense Data Computer collection software. Descriptive data were analyzed using analysis of variance (ANOVA), LSD with posthoc mean separation using Duncan Test for significant differences. ANOVA was performed using SPSS and analyzed at 5\% significance level. To determine the relationship within temperature and fermentation duration, and descriptor of sensory analysis, Component Principles Description of the Radar graph with the presentation of the number of panelists with score test results were used for coffee samples.

\section{Results and discussion}

The quality of coffee drinks is indicated by the unity of values of aroma, flavor, acidity and body. The smell of coffee can be detected as a result of volatile volatile compounds captured by human taste or smell. Yusianto
(1999) research results, states that high acidity will give the quality a better aroma of coffee. The trigonellin compound is an aroma precursor in coffee and in the presence of a process of roasting will produce volatile compounds. The volatile compound formed is a component of degradation of trigonellin and its main component (46\%) is pyridine. Flavor is a combination of the aroma that is captured by the human sense of smell and the sense of sediment that is captured by the sense of taste. Shrinkage is associated with a soluble nonvolatile compound, while the aroma is associated with volatile compounds.

Based on Table 1, the flavor profile of Robusta coffee derived from Bantaeng fermented with ohmic fermentation technology is categorized as excellent specialty coffee in the treatment of $18 \mathrm{hrs}$ fermentation time with temperature of $35^{\circ} \mathrm{C}$, with total score of 83.75 , while the total score of the lowest score on the fermentation treatment with a temperature of $30^{\circ} \mathrm{C}$ with a fermentation time of $6 \mathrm{hrs}$.

Table 1. Flavour profile of Robusta coffee result from fermentation ohmic tehnology with different periods time and temperature.

\begin{tabular}{|c|c|c|c|c|c|c|c|c|c|c|c|c|}
\hline $\begin{array}{l}\text { Coffee flavor } \\
\text { attributes }\end{array}$ & 党 & $\underset{n}{n}$ & 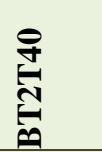 & అొ & שֶ & అొ & ֻ๊ & $\mathfrak{c}^{n}$ & 究 & $\stackrel{\infty}{=}$ & $\infty_{\infty}^{\infty}$ & 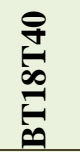 \\
\hline Fragrance/ Aroma & 8 & 8 & 8 & 7.25 & 7.25 & 7.25 & 7.25 & 8 & 8 & 8 & 8.5 & 8 \\
\hline Flavor & 7.75 & 7.5 & 7.75 & 6.75 & 7.5 & 7.75 & 7.75 & 7.75 & 7.75 & 7.5 & 8 & 7.5 \\
\hline After test & 7.75 & 7.75 & 7.5 & 6.75 & 7.5 & 7.75 & 7.75 & 7.75 & 7.5 & 7 & 7.75 & 7 \\
\hline Acidity & 8 & 8 & 8 & 6 & 7.25 & 7.75 & 7.5 & 7.75 & 7.5 & 6.5 & 7.75 & 7 \\
\hline Body mouth-feel & 7.75 & 7.75 & 7.75 & 7.5 & 7.75 & 8 & 8 & 7.75 & 7.75 & 7.25 & 8 & 8 \\
\hline Uniformity & 10 & 10 & 10 & 10 & 10 & 10 & 10 & 10 & 10 & 10 & 10 & 10 \\
\hline Balance & 8 & 7.5 & 7.5 & 6.75 & 7.5 & 7.75 & 7.75 & 8 & 7.75 & 7 & 8 & 7.25 \\
\hline Clean cup & 10 & 10 & 10 & 10 & 10 & 10 & 10 & 10 & 10 & 10 & 10 & 10 \\
\hline Sweetness/bitter & 8 & 7.75 & 7.75 & 6.75 & 7 & 7.5 & 7.5 & 7.5 & 7 & 6.75 & 7.75 & 6.75 \\
\hline Overall & 8 & 7.5 & 7.5 & 6.5 & 7.5 & 7.75 & 7.75 & 7.75 & 7.5 & 6.5 & 8 & 7 \\
\hline Total score & 83.25 & 81.25 & 81.75 & 74.75 & 79.75 & 81.75 & 81.75 & 82.25 & 80.75 & 76.75 & 83.75 & 78.5 \\
\hline $\begin{array}{l}\text { Notes: Quality sca } \\
<10=\text { outstanding } \\
\text { Total Score: }<80 . \\
\text { Outstanding specia }\end{array}$ & $\begin{array}{l}\text { fee } \\
\text { erfe } \\
\text { spe }\end{array}$ & 8 & 86 & & & 00 - & $00=$ & $\sigma \sim$ & 00 & $\mathrm{y} ; 9$ & -10 & \\
\hline
\end{tabular}

\section{Effect of fermentation temperature on Robusta flavor}

Referring to Fig. 1, it appears that at Robusta coffee coming from Bantaeng with a growing $800 \mathrm{~m}$ dpl based on test results of cup test value best flavor to a temperature of $35^{\circ} \mathrm{C}$, namely aroma (8), flavor (8), salt acidity (8), balance (8) and after test (8). For fermentation with a temperature of $40^{\circ} \mathrm{C}$ is best flavors of flavor, aroma, after test and mouth feel; while the fermentation temperature of $30^{\circ} \mathrm{C}$ Balance values obtained flavor, flavor, flavor Body and the fermentation temperature $35^{\circ} \mathrm{C}$. Sukrisno and Yusianto (2013), that the application of improper fermentation process will produce coffee beans with low flavor. Disability taste fermented or stinker is a severe type of disability. Fermentation defects can be avoided by doing the fermentation process appropriately and correctly. So for the treatment of fermentation with a combination of temperature and time of fermentation is the most fixed and the results of research carried out is a combination of temperature range $35-40^{\circ} \mathrm{C}$ and fermentation time with a range of 6-12 hrs is having defined average score 
grades of $81-83 \%$ where the score is categorized into the specialty coffee according to SCAA (2009).

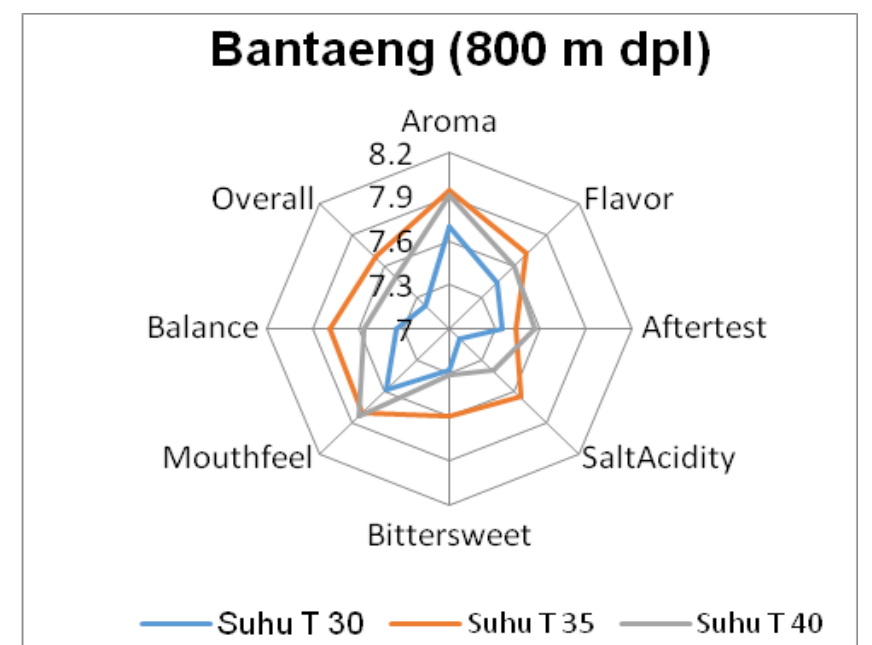

Fig. 1: Flavor profile of Robusta coffee from Bantaeng area at fermentation technology Ohmic Treatment by Temperature.

\section{Effect of fermentation time on Robusta flavor}

Based on Fig. 2, it is seen that the coffee coming from Bantaeng with altitude of $800 \mathrm{~m}$ asl the best place of the profile is $12 \mathrm{hrs}$. In the best aroma profile is found on the rice coffee from Bantaeng with a score of 8.1 on the fermentation of $18 \mathrm{hrs}$. In bitter sweet taste obtained value of 7.89 on fermentation time $2 \mathrm{hrs}$. The ohmic fermentation time in both regions resulting in a low overall flavor profile is $6 \mathrm{hrs}$ for Bantaeng, except for bittersweet attributes which have the highest value at 12 hrs fermentation temperature.

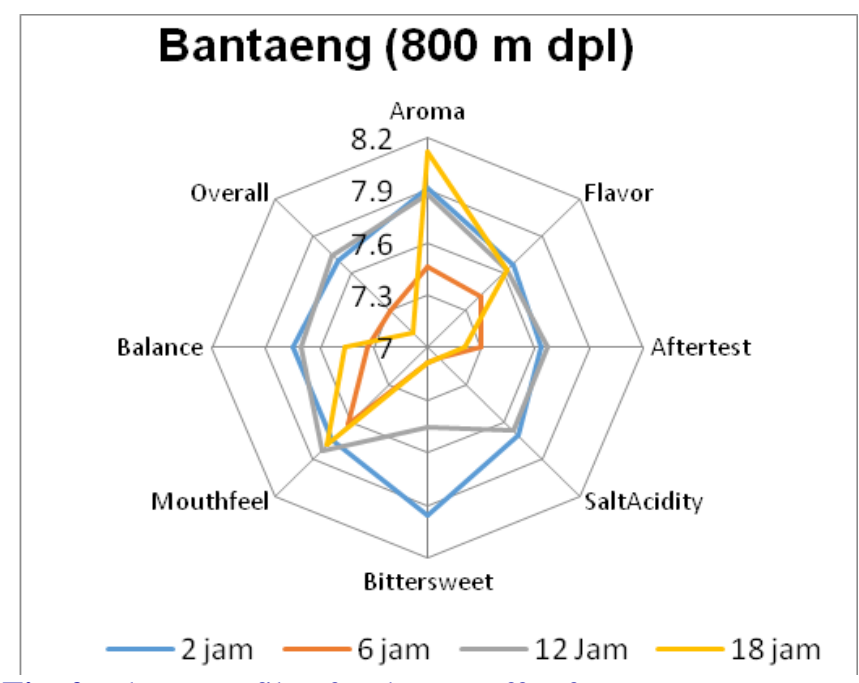

Fig. 2: Flavor profile of Robusta coffee from Bantaeng area at fermentation technology ohmic treatment by time fermentation.
Based on Fig. 3, the description of the flavors of coffee varieties of Robusta there are 19 identification of the flavor of coffee aroma originating from Bulukumba and Bantaeng with a profile of different flavor attributes of the two regions with different altitude places of growth that is $100 \%$ of the taste Wine identified in Robusta coffee originating from Bulukumba while Bantaeng $(0 \%)$ was not identified. Mild flavor and flowery obtained strong descriptions of flavor $(100 \%)$ in coffee derived from Bulukumba and Bantaeng, while flavor profiles honeyed $100 \%$ pda coffee originated from Bulukumba. Descriptions of sweet potato flavors of $88 \%$ aroma were identified in Bantaeng Robusta coffee while in Bulukumbah area as a result of cup test coffee aroma test on fermentation result of ohmic technology.

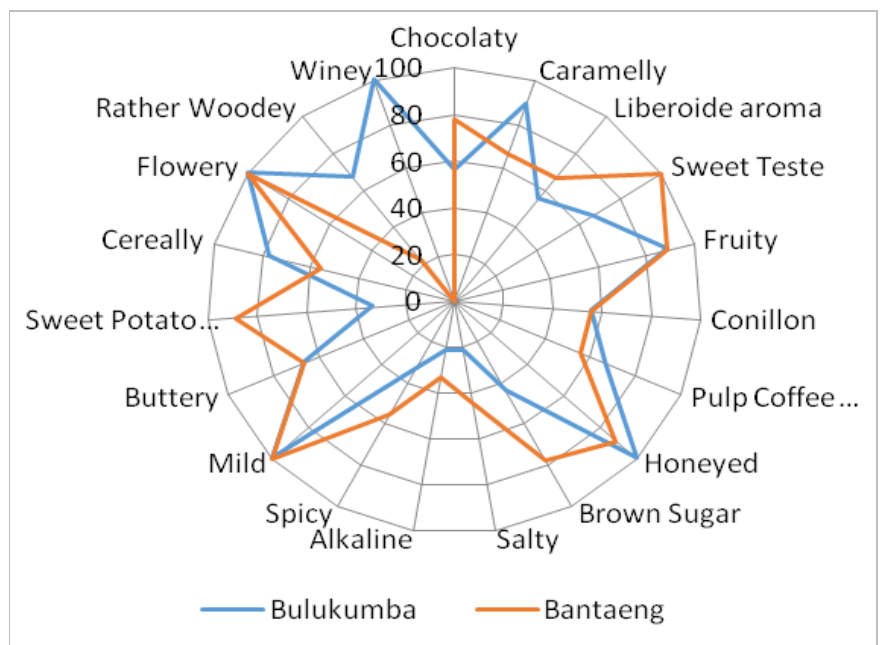

Fig. 3: Flavor profile of Bulukumba and Bantaeng Robusta coffee beans.

Marshall and Mejia (2011), said that the fermentation is carried out by fermentation can be set or controlled will produce the aroma of good coffee and will lead to the diversification of the taste in the cup of coffee, resulting in flavors other than coffee taste as generated in this study are lemon flavor, leaf series, herbal, chocolate, nutty, winey flavor, some of the other flavors.

\section{Conclusion}

Fermentation of Robusta coffee beans from areas Bantaeng (800 m dpl), using fermentation technology base ohmic, showed that:

1. Technology fermented beans with system fermentation ohmic was done in this study indicates that fermented beans with treatment variations in temperature and fermentation time 
ohmic found in Robusta coffee coming from Bantaeng with fermentation time $18 \mathrm{hrs}$ flavor, aroma and mouth feel of the best, 2 hrs bittersweet the best.

2. For a temperature optimum obtained in fermentation technology with ohmic is on arabica coffee from Bantaeng with a temperature of $35^{\circ} \mathrm{C}$ to produce flavor, aroma, salt acidity, mouth feel and balance the best.

3. Characteristic aroma and flavour coffee, as detected by a descriptive panel, influenced mainly by the one of the origin of coffee and / or treatment of fermentation temperature and fermentation time is done. This can be seen with the characteristic flavor of aromas found in coffee that comes from Banateng flavored chocolate, caramelly, sweet taste, connilon, honeyed, spicy, buttery, sweet potato and flowery that all of this is the distinguished flavors of the coffee origin typology.

\section{Conflict of interest statement}

Authors declare that they have no conflict of interest.

\section{Acknowledgement}

Authors are thankful to the Director General of Higher Education, Indonesia for funding the research activities through Research Grand Competition 2016.

\section{References}

Avallone, S., Brillouet, J.M., Guyot, B., Olguin, E., Gulraud, J.P., 2002. Involvement of pectolytic mikroorganisme in coffee fermentation. Int. J. Food Sci. Technol. 37, 191-199.

Avallone, S., Brillouet, J.M., Guyot, B., Olguin, E., Gulraud, J.P., 2001. Mikrobiological and biochemical study of coffee fermentation. Curr. Microbiol. 42, 252-256.

Baggenstoss, J., Poisson, L., Kaegi, R., Perren, R., Escher, F., 2008. Coffee roasting and aroma formation: Application of different time and temperature conditions. J. Agric. Food Chem. 56(14), 5836-5846.

Bytof, G., Knopp, S.E., Schieberle, P., Teutsch, L., Selmar, D., 2005. Influence of processing on the generation of gamma-aminobutyric acid in green coffee beans. Eur. Food Res. Technol. 220(3-4), 245-250.
Clarke, R.J., Macrae, 1989. Coffee. Elsevier Applied Science. London and New York.

FAO, 2004. Fermentation of Coffee-Control of Operation. "Good Hygiene Practices Along the Coffee Chairl".

Ferreira, G.F.P., De-Novaes, Q.S., Malta, M.R., DeSouza, S.E. 2013. Quality of coffee produced in the Southwest region of Bahia, Brazil subjected to different forms of processing and drying. Afr. J. Agric. Res. 8(20), 2334-2339.

Illy, A., Viani, R., 2005. Espresso Coffee: The Science of Quality. $2^{\text {nd }}$ Edn. Elsevier Academic Press, London, UK.

Jackels, S.C., Jackels, C.F., 2005. Characterization of the coffee mucilage fermentation process using chemical indicators: A field study in Nicaragua. J. Food Sci. 70, C321-C325.

Lin, C.C., 2010. Approach of improving coffee industry in Taiwan promote quality of coffee bean by fermentation. J. Int. Manag. Stud. 5(1), 154-159.

Marshall, E., Meijia, D., 2011. Traditional Fermented Food and Beverage for Improved Likehood. Food and Agriculture Organization of the United Nations, Rome.

Mondello, L., Costa, F., Tranchida, P.Q., Dugo, P., Presti, M.L., Festa, S., Fazlo, A., Dugo, G., 2005. Reliable characterization of coffee bean aroma propiles by automated headspace solid phase microextraction - gas chromatography - mass spectrometry with the support of a dual-filter mass spectra library. J. Sep. Sci. 28, 1101-1109.

Murthy, P. S., Naidu, M.M., 2011. Improvement of robusta coffee fermentation with microbial enzymes. Eur. J. Appl. Sci. 3(4), 130-139.

Owen, T., 2009. An updated pictorial guide to the roast process. Available from http://www.sweetmarias. com/roasting-VisualGuideV2.php Accessed 03.09

Redgwel, R., Fischer, M., 2006. Coffee carbohydrates. Braz. J. Plant Physiol. 18(1), 165-174.

Ribeiro, F.C., Borém, F.M., Giomo, G.S., Lima, R.R., Malta, M.R., Figueiredo, L.P., 2011. Storage of green coffee in hermetic packaging injected with $\mathrm{CO}_{2}$. J. Stored Prod. Res. 47, 341-348.

Salengke, S., 2000. Electrothermal Effects of Ohmic Heating on Biomaterials. Ph.D. Dissertation, The Ohio State University, Columbus, OH.

Salengke, S., Sastry, S.K., 2007. Models for ohmic heating of solid-liquid mixtures under worst-case heating scenarios. J. Food Engg. 83, 337-355.

Sastry, S. K., 2001. Ohmic heating and moderate electric field (MEF) processing. J. Engg. Food 21st Century. 
47, 785-791.

Schenker, S., Heinemann, C., Huber, M., Pompizzi, R., Perren, R., Escher, F., 2002. Impact of roasting conditions on the formation of aroma compounds in coffee beans. J. Food Sci. 67(1), 60-66.

Siswoputranto, P. S., 1993. Kopi International dan Indonesia. PenerbitKanisius Jakarta. $417 \mathrm{hlm}$.

Sivetz, M., Desrosier, N.W., 1997. Coffee Technology. The AVI Publ. Co. Inc., Wesport, Connecticut.

Specialty Coffee Association of America (SCAA), (2009a). What is specialty coffee?.Speciality Coffee Association of America. Retrieved from http://www.scaa.org/

Specialty Coffee Association of America (SCAA), 2012. SCAA Protocols-Cupping Specialty Coffee. SCAA.

Subedi, R.N., 2011. Comparative analysis of dry and wet processing of coffee with respect to quality and cost in Kavre District, Nepal: A case of Panchkhal village. Int. Res. J. Appl. Basic Sci. 2(5), 181-193.

Sukrisno, W., Yusianto., 2013. Optimizing of Arabica coffee bean fermentation process using a controlled fermentor. Pelita Perkebunan. 29(1), 53-68.

Yeretzian, C., Jordan, A., Badoud, R., Lindiger, W. 2002. From the green bean to the cup of coffee: investigating coffee roasting by on-line monitoring of volatiles. Eur. Food Res. Technol. 214, 92104.

Ramaswamy, R., Balasubramaniam, V.M., Sastry, S.K., 2003. Ohmic Heating of Foods Fact Sheet for Food Processors. Ohio State University, Columbus.

Yusianto, 1999. Komposisikimia Biji Kopidan Pengaruhnyaterhadap Citarasa Seduhan. Warta Pusat Penelitian Kopi dan Kakao. 15(2), 190-202.

\section{How to cite this article:}

Reta., Mursalim., Muhidong, J., Salengke., 2017. Characteristic flavour of Robusta coffee from South Sulawesi after fermentation by ohmic technology. Int. J. Curr. Res. Biosci. Plant Biol. 4(7), 33-38.

doi: https://doi.org/10.20546/ijcrbp.2017.407.004 